theme for their books. Curtis, in particular, devotes her Chapter 46 to an analytical survey of "The Evidence for Evolution". Only Curtis and Graham list "Creation" in their index, and none of the six books gives any account of contemporary quarrels with creationists. This may be the right approach. But we commend to all who teach introductory biology the excellent account of such quarrels, past and present, to be found in Luria, Gould and Singer's A View of Life (for review see Nature 295, 479; 1982).

We ended our 1980 review by noting that the prices of the seven texts were all approximately the same (ranging from $\$ 16.50$ to $\$ 20)$. The present texts remain roughly equal in price ( $\$ 24$ to $\$ 28$, representing an average inflation rate of 12 per cent per annum). Although the economic forces underlying this effective parity in price are understandable, the phenomenon is remarkable when one considers the substantial differences in quality of production and quality of professional effort among these books. Why do the dozen or more less-excellent books survive, some of them going through edition after edition? A partial explanation is suggested by a very rough calculation that several millions of dollars in profits accrue annually from the sale of introductory biology texts, so that capture of less than one per cent of the market can be financially rewarding. Whatever the market forces, they serve us all well when they continue to produce, relatively cheaply, books of the quality of Keeton, Curtis and the others at the top of the range.

Edward C. Cox is Chairman of, and Robert $M$. May Professor in, the Department of Biology at Princeton University, where they jointly teach an introductory biology course.

\section{Before the bridges are built}

\section{Robert H. Smith}

\section{Insect Herbivory.}

By I.D. Hodkinson and M.K. Hughes. Pp.96.

Modelling. By John N.R. Jeffers. Pp.80. Animal Population Dynamics.

By R. Moss, A. Watson and J. Ollason. Pp.80.

Chapman \& Hall: 1982.

Each book £2.95, \$6.50.

STUDENTS of ecology in the 1950s and 1960 s were reared on a diet based mainly around Odum's Fundamentals of Ecology (Saunders, 1953); in the following decade students would more likely have had to digest either Krebs' Ecology (Harper \& Row, 1972) or Ricklefs' Ecology (Nelson, 1973), but already there were appearing specialist texts to supplement the basic fare. The Institute of Biology series Studies in Biology, published by Edward Arnold, set off to a good start in 1966 with Phillipson's Ecological Energetics and now includes several ecology titles. Publishers Chapman \& Hall have entered the 1980 s with a new series, Outline Studies in Ecology, and it now seems to be accepted that ecology students are recommended a number of smaller books on specific topics rather than a single, comprehensive text. How good a job do these short texts do?

Insect Herbivory considers what plants can provide insects with, how insects are adapted to herbivory, and what the ecological consequences are. The book is well produced with an extensive bibliography (222 references for less than 60 pages of text) and to me, a non-specialist, it seemed a very useful introduction to insect-plant interactions.

Modelling is based around six questions, the two most pertinent being "Why do I need a model?" and "How do I know when to stop?"' The book is a clearly written summary of the technology of ecological modelling as seen by John Jeffers and is necessarily a personal overview, but it contains much wisdom that would benefit any ecologist, whether student or teacher. Sadly many of the models given as examples are described too briefly to be of much use to students, and not all of them are referenced. An appendix contains the checklist of questions for intending modellers published by the Institute of Terrestrial Ecology.

I found Animal Population Dynamics a most enjoyable read, but it is unfortunately severely flawed as a student text. The style is free-flowing and almost conversational, which is fine except when the excessive use of "this" and "these" leads to ambiguity. Considerable stress is laid upon behavioural mechanisms of population regulation and on the possibility that rapid genetic change may often be bound up with population fluctuations, but the majority of secondyear undergraduates would be unable to evaluate the validity or generality of the arguments. One figure (4.7) has an unlabelled axis and another (7.1) uses undefined shading conventions - all right for me as I had read the original paper, but confusing for students. It is a pity that this potentially exciting textbook was spoilt by lack of attention to detail.

The authors of Animal Population Dynamics finish their book with the hope that "what we have written today, you will disprove tomorrow". Perhaps the role of these specialist texts is to act as stepping stones until they can be kicked away and replaced by a bridge linking different areas of ecology in an acceptable synthesis; the stepping stones will suffice for the time being.

Robert H. Smith is a Lecturer in Applied Zoology at the University of Reading.

\section{Populations of all sorts}

\author{
Michael B. Usher
}

Mathematical Methods of

Population Biology.

By F.C. Hoppensteadt.

Cambridge University Press: 1983.

Pp.150. Hbk f15, \$29.95;

pbk $£ 6.50, \$ 12.95$.

Wildlife Population Ecology.

Edited by James S. Wakeley.

Pennsylvania State University Press:

1982. Pp.450. Hbk £14.85, \$24.10;

pbk £9.60, \$15.55.

A FEW biologists view population biology more as a branch of applied mathematics, whilst others see the subject as a respectable form of natural history. These extreme attitudes are evident in the two books under review.

Mathematical Methods of Population Biology is a very concise book which covers only a few topics. Mathematicallyunsophisticated biologists will have some difficulty with the first and second chapters, and will find the final chapter especially tough going. The book starts with population dynamics, looking at models in refreshingly new ways. It progresses through some Matrix models to Markov chains applied to bacterial and human genetics, and then to a short chapter on perturbation methods which paves the way for a discussion of a number of dispersal and diffusion processes.

Little concession is made to the general lack of mathematical ability amongst biologists: a trivial example is the statement (p.35),

$$
\lambda_{1}^{2}+1=\lambda_{1}+1+1=\lambda_{1}+2,
$$

when, on the previous page,

$$
\lambda_{1}=(1+\sqrt{5}) / 2 \text {. }
$$

Care must be also exercised in taking statements at their face value as there are mistakes, for example in the transposition of $a$ and $b$ in the formulae on page 29 .

Frustration with having to dip into a variety of different journals led James Wakeley to bring together a collection of articles, reproduced in facsimile as Wildlife Population Ecology. Twelve papers deal with birds, and the remaining 19 either with mammals or mammal-based topics. The book is divided into two parts. The first considers the intrinsic components of populations - birth and death processes, dispersal, population growth and cycles. The second brings together some of the extrinsic factors that influence populations - the effects of climate, predators and competition. The distinction between the two parts is, however, somewhat fuzzy since physiological stress and behaviour fit comfortably into neither part.

Both of these textbooks have serious defects. Mathematical Methods of Population Biology is too condensed, 